\title{
Local Food Material Processing Technology from Taro Tuber: Composite Study of Flour Substitution Materials on Taro Puff Banana Products
}

\author{
Enita Rahayu ${ }^{1}$, Endang Mulyatiningsih ${ }^{2}$ \\ \{enita_rahayu.2017@student.uny.ac.id ${ }^{1}$, ememulya63@gmail.com² ${ }^{2}$. \\ Universitas Negeri Yogyakarta, Indonesia ${ }^{1,2}$
}

\begin{abstract}
This study aims to find the right formula in making Taro puff pastry and knowing the community's acceptance of Taro puff pastry. The type of research used in making this product is the 4D development model (Define, Design, Develop, Dissemination). The subjects of the study were Culinary Engineering Education Yogyakarta students with a total of 35 students. Data collection methods used are observation, interviews, and documentation. The results obtained from this study are: 1) the right recipe for taro puff pastry products is by substituting taro flour as much as $30 \%$, using high dough processing techniques, then finishing with baking techniques using a temperature of $180^{\circ} \mathrm{C}$ for \pm 45 minutes, and 2) test the preference for taro puff pastry products with substitution of taro flour showed that the product was acceptable to consumers with a favorite percentage of taro puff pastry as much as $96 \%$.
\end{abstract}

Keywords: taro, puff pastry, taro puff pastry

\section{Introduction}

Indonesia has a wealth of natural resources, especially in the types of local food crops such as tubers, but until now the use of tubers is not optimal. One of them is local ingredients for taro tubers. Taro or Colocasia esculenta is known as food called yam in Brazil [1]. In Brazil, taro is an unusual plant from other plants because farmers mainly used for substitution materials cultivate it [2]. In the opinion of the United Nations Food and Agriculture Organization (FAO), in 1993 and 2013, the main producers of taro tubers were African countries with $75.2 \%$ of world production, followed by Asia (20.8\%), Oceania (3.8\%) and America [3]. (0.3\%) Taro is included in one type of tubers. Taro grows easily in Indonesia. In 2011 , in the implementation of alternative food area exhibition activities, the number of taro production or production from several regions in Indonesia could reach 661 quintals/hectare [4]. The words of this patisserie come from French, namely Pậtisserie means cakes. Because of that, the patisserie can be interpreted as a science or knowledge that learns about the ins and outs of cakes, both continental, oriental and Indonesian cakes ranging from preparation, processing to the presentation. In this era, patisserie is learned about a science and art in processing and serves a variety of cakes, both traditional and modern pastries. Patisserie products are a popular product, also a type of food favored by Indonesian people [5]. Patisserie products in the community are known as sweet bread, fresh bread, pastries/cookies, cakes, archipelago cakes, and pastry products. Therefore, researchers tried to make processed 
bread and cake products from the substitution of taro tuber flour, namely puff pastry products. Puff pastry is made from dough filled with sweet or savory stuffing, this puff pastry consists of varied products and has multi-layered skin, puff pastry is a product made from unleavened dough and developer ingredients [6]. Puff pastry is one of the lightest and crispy pastry products made from some flour and fat. The layers are formed due to the use of margarine or butter and when baked the water is trapped between the layers in the dough, together with hot water steam pushes the mixture until it expands. Puff pastry expands higher and is richer in flavor than other pastries. A sheet found on this pastry mixture can be produced by mixing folding big dough or commonly called margarine pastry and also known as corsvet [7]. The uniqueness of this pastry dough is that the folded fat is not mixed into a mixture but is smeared thinly and evenly on the surface of the mixture. Then the dough is folded and then thinned again. In the process of folding and then coating the corsvet and thinning the dough is done repeatedly so that the final mixture that looks like a single sheet is obtained. When roasting or burning in the oven, the sheets in the mixture will expand so that the final result of the cake shows a lot of thin, fused layers. Puff pastry can expand higher and create multiple lines and is richer in flavor compared to other pastries [8]. In this study, the puff pastry will be substituted with taro into the name Taro Puff Pastry [7]. The purpose of substitution research of taro tuber flour in the manufacture of Taro Puff Pastry is the use of local food ingredients as a basic ingredient of patisserie products and to add nutritional value to the product, given the lack of public knowledge about taro tuber processing. By substituting taro tubers in the manufacture of patisserie products, it is expected to be accepted by the general public both regarding taste, aroma, texture and different shapes.

\section{Methode}

\subsection{Procedure}

Research procedure for developing a dictionary with pictorial equipment Research using four stages, namely define, design, develop and disseminate. Define scene is the stage of gathering information including curriculum analysis, student analysis, material analysis and formulating goals. The design phase is the design stage of the researcher making a prototype or product design. The development phase is the stage of producing the final product after going through the process of validation, revision, and trial. The disseminate stage is the stage of dissemination carried out by researchers, namely by field testing on students of the Faculty of Engineering, Yogyakarta State University.

\subsection{Data, instruments and data collection techniques}

In this study, the data collected from observations were used to observe and find out the problems in the lack of utilization of local materials in Indonesia, interviews were conducted to determine the state of local material use in the community, validation was used to conclude the evaluation results of experts/experts, questionnaires were used to conclude the feasibility of taro puff pastry which is expected to be accepted by the general public both in terms of taste, aroma, texture and different shapes.

\subsection{Data analysis technique}


Data analysis techniques used in this study are descriptive and quantitative or expert appraisal. Includes data that can be calculated consisting of taste, color, texture, and aroma. Quantitative is data that can be measured in this study. Quantitative information is obtained from the results of the panelists' acceptance of the products received and those not received.

\section{Results and Discussion}

In the process of making Taro Puff Pastry uses a type of R \& D research, the 4D model consists of several stages, namely define (product analysis), design (product design), development (manufacturing and product testing), and dissemination (product exhibition)[9], [10].

\subsection{Define Stage}

Analysis of the taro puff pastry formula is done by collecting basic recipes from 3 different sources. The following are the results of the trial of the three reference formulas found in the table below.

Table 1. Puff Pastry Reference Formula

\begin{tabular}{llccc}
\hline No. & Name of material & $\begin{array}{c}\text { Reference } \\
1\end{array}$ & $\begin{array}{c}\text { Formula } \\
\text { Reference } \\
2\end{array}$ & $\begin{array}{c}\text { Reference } \\
3\end{array}$ \\
\hline 1 & Cakra Flour & $1000 \mathrm{gr}$ & $500 \mathrm{gr}$ & $310 \mathrm{gr}$ \\
2 & Segitiga flour & - & - & $230 \mathrm{gr}$ \\
3 & Salt & $25 \mathrm{gr}$ & $10 \mathrm{gr}$ & $10 \mathrm{gr}$ \\
4 & Water & $500 \mathrm{gr}$ & $250 \mathrm{gr}$ & $240 \mathrm{gr}$ \\
5 & Corvettes & $500 \mathrm{gr}$ & $300 \mathrm{gr}$ & $510 \mathrm{gr}$ \\
6 & Lemon Juice & - & - & $25 \mathrm{ml}$ \\
7 & Butter & $100 \mathrm{gr}$ & $75 \mathrm{gr}$ & $55 \mathrm{gr}$ \\
8 & Egg & $150 \mathrm{gr}$ & - & - \\
\hline
\end{tabular}

The technique used in making Taro Puff Pastry is in a straight dough. The straight dough technique is the most used technique in making puff pastry products because it is straightforward to process. In this process, all ingredients are put together then put the liquid ingredients while being dyed evenly. Based on the three references to the formula and the evaluation of characteristics accompanied by the consideration of the supervisor, the first formula is chosen as the formula for the recommendation of the research product [8]. This first formula can produce puff pastry products that are crisp, savory, and layered as expected by consumers. The following are the results of the trials of the three formulas. From the test of the three recipes, the following is a reference formula selected for the manufacture of taro puff pastry products. 
Table 2. Results of puff pastry trials

\begin{tabular}{cccc}
\hline \multirow{2}{*}{ Characteristic } & \multicolumn{3}{c}{ Trial Results } \\
& Formula 1 & Formula 2 & Formula 3 \\
\hline Color & Good & Good & Good \\
Aroma & Good & Good & Good \\
texture & Crispy & less crispy & less crispy \\
Taste & savory & More savory & savory \\
\hline
\end{tabular}

\subsection{Design Stage}

In the design phase, the formula that has been selected will then be substituted with local food ingredients, namely with taro. This stage there is a possibility that the trial will be carried out more than once based on the evaluation and input by the supervisor/expert at the time of validation. In making this taro puff pastry, the substitution of the pure taro flour used was $0 \%$, $20 \%, 30 \%$, and $40 \%$. The following is a draft product formula for taro puff pastry.

Table 3. Design of the Taro Puff Pastry product formula

\begin{tabular}{clcccc}
\hline No. & \multicolumn{1}{c}{ Material } & $\begin{array}{c}\text { Selected Reference } \\
\text { Formula }\end{array}$ & $\begin{array}{c}\text { Design of } \\
\text { Formula } 1\end{array}$ & $\begin{array}{c}\text { Design of } \\
\text { Formula 2 }\end{array}$ & $\begin{array}{c}\text { Design of } \\
\text { Formula 3 }\end{array}$ \\
\hline 1 & Cakra Flour & $200 \mathrm{gr}$ & $160 \mathrm{gr}$ & $140 \mathrm{gr}$ & $120 \mathrm{gr}$ \\
2 & TaroFlour & - & $40 \mathrm{gr}$ & $60 \mathrm{gr}$ & $80 \mathrm{gr}$ \\
3 & Salt & $5 \mathrm{gr}$ & $5 \mathrm{gr}$ & $5 \mathrm{gr}$ & $5 \mathrm{gr}$ \\
4 & Ice Water & $80 \mathrm{gr}$ & $80 \mathrm{gr}$ & $80 \mathrm{gr}$ & $80 \mathrm{gr}$ \\
5 & Corvettes & $80 \mathrm{gr}$ & $80 \mathrm{gr}$ & $80 \mathrm{gr}$ & $80 \mathrm{gr}$ \\
6 & Butter & $20 \mathrm{gr}$ & $20 \mathrm{gr}$ & $20 \mathrm{gr}$ & $20 \mathrm{gr}$ \\
7 & Vanilla essence & $1 / 4 \mathrm{tsp}$ & $1 / 4 \mathrm{tsp}$ & $1 / 4 \mathrm{tsp}$ & $90 \mathrm{gr}$ \\
8 & Butter cream & $100 \mathrm{gr}$ & $100 \mathrm{gr}$ & $100 \mathrm{gr}$ & $100 \mathrm{gr}$ \\
\hline
\end{tabular}

The selected reference formula is then tested again to find the right method with the proper comparison. The following are the results of the trials of the three recipes above.

Table 4. Results of the trial of Taro Puff Pastry

\begin{tabular}{lccc}
\hline \multirow{2}{*}{ Characteristic } & \multicolumn{3}{c}{ Trial Results } \\
\cline { 2 - 4 } & Formula 1 & Formula 2 & Formula 3 \\
\hline Color & Pale Red & Pink & Brownish red \\
Aroma & Good & Good & Good \\
texture & Crispy, layered texture & Crispy, layered texture & layered Less crispy, less \\
Taste & Savory & More savory & layered \\
& & & savory \\
\hline
\end{tabular}


Based on the three formulas, the best recipe is the design of the second formula using $30 \%$ taro flour substitution formula because it has excellent color characteristics compared to other methods. It has a crisp and layered texture, pleasant aroma, and savory taste.

\subsection{Stage Develop}

At this stage, an expert appraisal on the products of taro puff pastry was carried out, and there were several appropriate changes from the input from the expert during validation I and II. The following is an explanation of the changes in the process at the first and second validation.

\subsubsection{Validation I}

The results of the trial on the first validation with a substitution of taro flour comparison of 30:70 (pure taro flour: high protein wheat flour) for the amount of formula has no change but has a text that is still as hard as hard. To anticipate this, the eggs are only replaced with egg yolks, with the hope that the texture of taro puff pastry can be more tender.

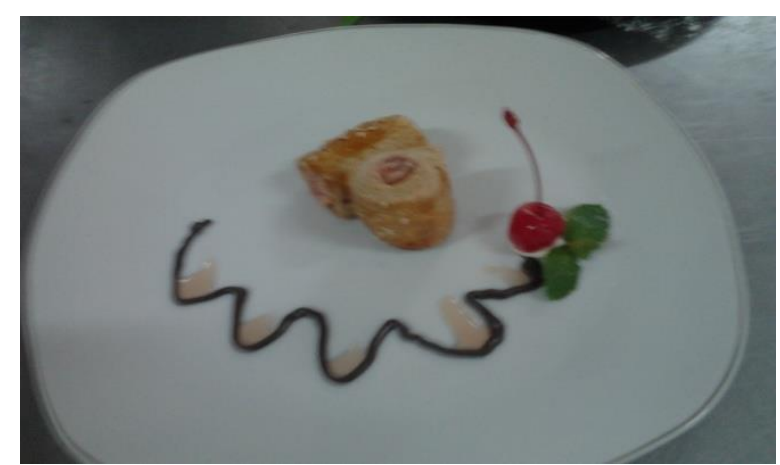

Fig 1. Taro Puff Pastry validation II

\subsubsection{Validation II}

Invalidation II, the comparison used remains the same, namely 30:70 (taro flour: high protein flour). In the second validation stage, there was a change that was better than the time of validation I. The taro puff pastry product at the second validation already had a crunchy and tender texture from the time of validation I. the taste of taro puff pastry was sweet enough, for the form to change more attractive and given an additional pink color to increase the attractiveness of the product. The aroma of this product is excellent. 


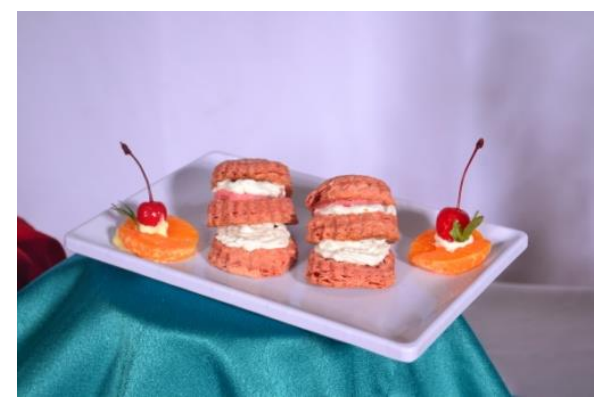

Fig 2. Taro puff pastry in stage II

\subsection{Disseminate stage}

At this stage, a limited-scale panelist test is conducted, so it is obligatory to make changes by the panelist's advice by consulting the supervisor. After the product is ready, then enter the full-scale preference test (exhibition).

\subsubsection{Panelist (limited)}

The product acceptance test was carried out by 30 semi-trained panelists who were taken from students of culinary majors in Yogyakarta State University.

Table 6. Final results of the recipe after panelist testing

\begin{tabular}{clcc}
\hline No. & \multicolumn{1}{c}{ Material } & Use & Changes after panelist test \\
\hline 1 & Cakra Flour & $140 \mathrm{gr}$ & $140 \mathrm{gr}$ \\
2 & TaroFlour & $60 \mathrm{gr}$ & $60 \mathrm{gr}$ \\
3 & Salt & $5 \mathrm{gr}$ & $5 \mathrm{gr}$ \\
4 & Ice Water & $80 \mathrm{gr}$ & $80 \mathrm{gr}$ \\
5 & Corvettes & $80 \mathrm{gr}$ & $80 \mathrm{gr}$ \\
6 & Butter & $20 \mathrm{gr}$ & $20 \mathrm{gr}$ \\
7 & Egg Yolks & $80 \mathrm{gr}$ & $80 \mathrm{gr}$ \\
8 & Red Color & - & Pinker \\
9 & Essence vanilla & $1 / 4 \mathrm{tsp}$ & $1 / 4 \mathrm{tsp}$ \\
10 & Buttercream & $100 \mathrm{gr}$ & $100 \mathrm{gr}$ \\
\hline
\end{tabular}

Final test results for product acceptance for a limited scale trial are as follows:

Table 7. Test of Taro Puff Pastry Panelists

\begin{tabular}{cc}
\hline Value Scale & Assessment Criteria \\
\hline Very disliked & - \\
Not preferred & 1 \\
Preferred & 13 \\
Preferably & 16 \\
\hline
\end{tabular}




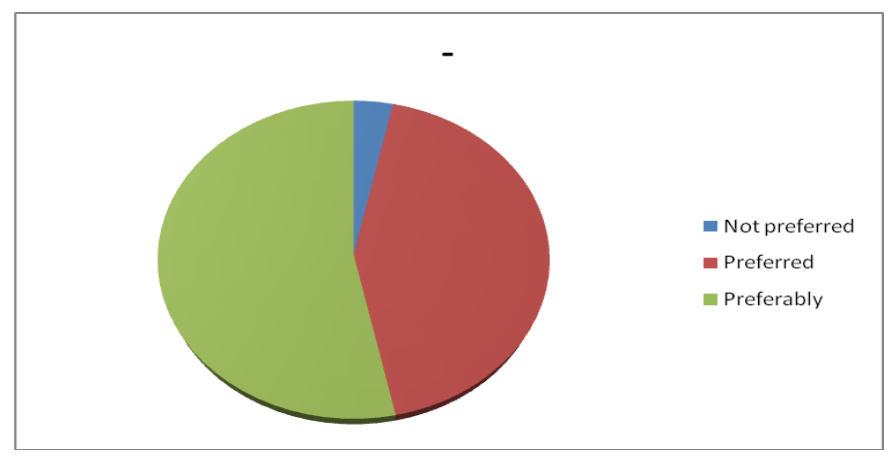

Fig 3. Diagram of panelist taro puff pastry test

According to the table and figure above, it can be concluded that $53 \%$ of panelists like rato puff pastry products, $44 \%$ like rato puff pastry products, and only $3 \%$ don't like rato puff pastry products.

\section{Product Exhibition}

After doing various trials, then get the final recipe that produces better products. Products that enter this stage are products that have passed panelist tests. The final result of this dissemination stage is by testing product acceptance at the exhibition visitors as many as 35 people. Here is a recipe for taro puff pasty products.

Table 8. Taro puff pasty product recipes

\begin{tabular}{|c|c|c|}
\hline No. & Bahan & Penggunaan \\
\hline 1 & Cakra Flour & 140 gr \\
\hline 2 & TaroFlour & $60 \mathrm{gr}$ \\
\hline 3 & Salt & $5 \mathrm{gr}$ \\
\hline 4 & Ice Water & $80 \mathrm{gr}$ \\
\hline 5 & Corvettes & $80 \mathrm{gr}$ \\
\hline 6 & Butter & $20 \mathrm{gr}$ \\
\hline 7 & Egg Yolks & $90 \mathrm{gr}$ \\
\hline 8 & Red Color & $1 / 4$ tsp \\
\hline 9 & Essence vanilla & $1 / 4$ tsp \\
\hline 10 & Buttercream & $100 \mathrm{gr}$ \\
\hline
\end{tabular}

In the exhibition's favorite test, it was different from the analysis of preference at the panelists, because the panelists' tests were assessed including color, taste, aroma, and texture. While at the time of testing the exhibition preference is only asked for an assessment of likes or dislikes. So that the percentage of people who don't like taro puff pastry products is also different [11]-[13]. 
Table 9. Test the preferences of the dissemination stage

\begin{tabular}{ccc}
\hline \multirow{2}{*}{ Product Name } & \multicolumn{2}{c}{ Criteria } \\
& Like & Dislike \\
\hline Taro Puff Pastry & 35 & 0 \\
\hline
\end{tabular}

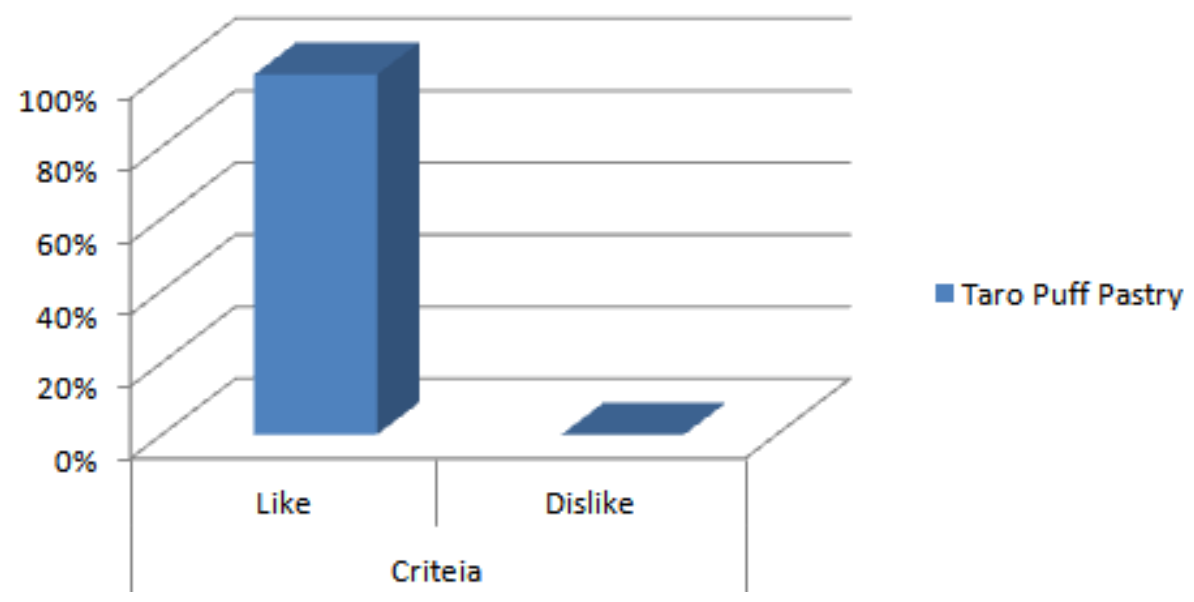

Fig 4. Test diagram of the preferred dissemination stage

At the dissemination stage of the table and the picture above it can be concluded that taro puff pastry is liked and accepted by the community.

\section{Conclusion}

The conclusion of this report is based on the results of observations, analysis, and data obtained from the results of the study are the right recipe for taro puff pastry products is to substitute kilmpul taro flour with a ratio of $30 \%$ kimpul taro flour and $70 \%$ high protein flour using baking techniques. The acceptance of consumers at the time of the panelists who received taro puff pastry products were $53 \%$ of the panelists were very fond of rato puff pastry products, $44 \%$ liked rato puff pastry products, and only $3 \%$ did not like rato puff pastry products. The level of preference in the dissemination stage for taro puff pastry products is $100 \%$ preferred.

\section{Acknowledgments}

Thank-you notes the author would like to thank the Family Welfare Education, Postgraduate, Yogyakarta State University for accompanying the author to write this article, they deserve. 


\section{Reference}

[1] S. E. S. Dos, M. P. Cereda, G., and Pedralli, "Puiatti m. Denomina, c̃oes populares dasesp'ecies de Dioscorea e Colocasia no Brasil.," Rev. Tecnol. e Ci^encia Agropecuária, vol. 1, pp. 37-41, 2007.

[2] Brasil, "Manual de Hortali, cas Nªo-Convencionais," 1st ed. Bras'ılia.MAPA/ACS, p. 1-92 p, 2010.

[3] T. A. Alfle, "Partial substitution of wheat flour with taro (Colocasia esculenta) flour on cookie quality," Rev. Ci^encias Exatas e Nat., vol. Vol.18, no, p. 2, 2016.

[4] S. Nurbaya, "Use of Yellow Tuber Fleshy (Colocasia Esculenta (L.) Schott) in the Making of Cookies, FTP of Brawijaya University Malang," Agro-Industry, J. Food, vol. Vol. 1 No., p. p.46-55, 2013.

[5] Aini and S. Nurul, "The Influence of Learning Strategies, Learning Styles, Practical Facilities, and Media on Learning Outcomes of Patisseries in Gerbangkertasusila," J. Vocat. Educ., p. 88.

[6] S. . Cauvain, Young, L.S.BakingProblemsSolve. Cambridge: Woodhead publishing, 2001.

[7] A. Hoesni, Perfect Pastry. Jakarta, Indonesia: Jakarta: PT Gramedia Utama., 2001.

[8] Nunung, Antigagal Secrets to Making Popular Cakes. Jakarta, INDONESIA: Dementia Library. Jakarta., 2009.

[9] R. Brewer, "Design and Development Testing," EE Eval. Eng., vol. 48, no. 8, pp. 4043, 2009.

[10] W. J. Aston, "Product design and development," Biosens. Bioelectron., vol. 7, no. 2, pp. 85-89, 1992.

[11] G. Forrai and G. Bankovi, "On the food favoritism of twins," Acta Physiol Hung, vol. 64, no. 1, pp. 25-32, 1984.

[12] P. Rozin, "Food Preference," in International Encyclopedia of the Social \& Behavioral Sciences, 2001, pp. 5719-5722.

[13] A. Drewnowski, "Genetic markers, taste responses, and food preferences," ACS Symposium Series, vol. 825. pp. 52-64, 2002. 